\title{
ÇİGİ FİLMLERDE KÜRESEL VE YEREL KÜLTÜRÜN İNŞASI: CAİLLOU VE PEPEE ÖRNEĞİ
}

\section{CONSTRUCTION OF GLOBAL AND LOCAL CULTURE IN CARTOONS: CAILLOU AND PEPEE SAMPLE}

\section{ФОРМИРОВАНИЕ МИРОВОЙ И НАЦИОНАЛЬНОЙ КУЛЬТУРЫ НА ПРИМЕРЕ ПЕРСОНАЖЕЙ МУЛЬПЛИКАЦИОННЫХ ФИЛЬМОВ ДЖАЛОВ И ПЕППЕ}

Şakir EŞİTTi் ${ }^{* *}$

\section{ÖZ}

Bu çalışmada küresel kültür ile yerel kültür arasında kitle iletişim araçları üzerinden, özellikle televizyon üzerinden, kültürel bir mücadele yaşandığı ve bu mücadele alanlarından birinin de çizgi filmler olduğu görüşü savunulmaktadır. Ulus aşırı üne sahip çizgi filmleri çocukların yoğun bir şekilde izlemesi, Batılı kültüre ait değerlerin ve yaşam biçimlerinin giderek yerel kültürleri etkisi altına almasına neden olmakta bu durum, yeni nesillerin kendi kültürlerine yabancılaşmalarına ve kültürel kimlik bunalımı yaşamalarına sebebiyet vermektedir. Medya emperyalizmi ve kültürel emperyalizm kavramlarının tartışıldığ 1 bu çalışmada, Türkiye'de son yıllarda üretilen yerli çizgi filmler aracılığıyla küresel kültüre ait değerler karşısında, Türk kültürüne ait değer ve pratiklerin yeniden üretildiği, bu yolla da Türk kültürüne ait değerlerin çocuklar tarafından öğrenilmesine katkı sağlandığı görüşü ileri sürülmektedir. Bu bağlamda Türkiye'de en çok izlenen 'ulus aşırı üne sahip' çizgi filmlerden "Caillou" isimli çizgi film ile yerel olarak en çok izlenen çizgi filmlerden biri olan "Pepee" isimli çizgi film, tematik analiz yönteminden faydalanılarak çözümlenmiş, küresel ve yerel kültüre ait değerlerin bu çizgi filmlerde nasıl işlendiği ve hangi kültürel değerlerin bu yolla 'ekilmeye' çalışıldığı hususu ortaya konulmuştur.

Anahtar Kelimeler: Kültür aktarımı ve çizgi filmler, kültürel emperyalizm, medya emperyalizmi, Pepee, Caillou

\section{ABSTRACT}

This study advocates the view that through the mass media, especially through television, a cultural struggle between local culture and global culture takes place and one of the main areas of this struggle is the cartoons. Intensive consumption of the transnational cartoons by the children, triggers the penetration of the Western values and lifestyles to the local cultures and this situation leads cultural identity crisis and the alienation of the new

* Bu çalışma 15-17 Haziran 2016 tarihleri arasında gerçekleştirilen "Anadolu'da Kültür ve İletişim: Geçmiş, Günümüz ve Gelecek" isimli Uluslararası Sempozyumda bildiri olarak sunulmuş, "Kültürel Mücadele Alanı Olarak Çizgi Filmler: Cailou ve Pepee İsimli Çizgi Filmlerin Karşılaştırılması" başlıklı bildiri metninin yakın bir zamanda basılacağı yazarlara iletilmiştir. Bu makale adı geçen bildirinin geliştirilmiş halidir.

** Yrd. Doç. Dr., Ardahan Üniversitesi, İktisadi ve İdari Bilimler Fakültesi, Öğretim Üyesi, eposta: sakiresitti@yahoo.com.10.17498/kdeniz.279674 
generations to their cultural values and lifestyles. In this study where cultural imperialism and media imperialism is broadly discussed, it is advocated that through the domestic animated cartoons produced in recent years in Turkey, in response to transferring the values of the global culture, the values of the Turkish culture and practices has been re-produced and this contributes to learning of the local cultural values and practices by the new generations. In this context, "Caillou" named one of the most watched transnational renowned cartoons and "Pepee" named locally one of the most watched cartoons in Turkey has been examined through the thematic analysis method, in this way the study reveals how the local and global values have been reprocessed and which cultural values are tried to be 'cultivated' in this cartoons.

Keywords: Cultural transfer and cartoons, cultural imperialism, media imperialism, Pepee, Caillou

\section{Аннотация}

Целью данного исследования - раскрыть противоречивые факторы в области формирования мировой и национальной культуры, в частности культуры определенной местности, на примере мультипликационных фильмов, которые являются одним из элементов средств массовой информации на телевидении, в результате чего происходит так называемая идейная борьба за культуру. На сегодняшний день это является одной из проблем формирования культурного общества. По данным проведенного мониторинга среди детей известные транснациональные мультфильмы пользуются большим интересом, которые построены на культурных ценностям запада и презентуют тот образ жизни. При этом происходит влияние на национальную местную культуру, что приводит к появлению нового поколения, у которого проявляется отчуждение от своей собственной культуры, и порождает так называемый кризис идентичности. В целях сохранения национальной идентичности, в Турции за последние годы отмечается динамичный рост производства анимационных фильмов, построенных на самобытности и национальных особенностях турецкой культуры, с целью воспитания у детей любви к ценностям своей культуры.

Проведенный тематический анализ наиболее рейтинговых анимационных фильмов «Джаилло» и «Пеппе» показывает, каким образом и в каком направлении презентовать просмотр подобных фильмов, акцентировать внимание детей на национальных ценностях.

Ключевые слова: исследования в культуре, аннимационные фильмы, культурный империализм, Пеппе, Джаилло

\section{GİRIŞ}

İletişim teknolojileri alanında yaşanan gelişmeler her geçen gün bireylerin yaşamlarını etkilemekte, dünya giderek küresel bir köy haline dönüşmektedir. Küreselleşmenin getirilerinden biri olan küresel kültür, gitgide kendine geniş yaşam alanları bularak yaygınlaşmaktadır. Kültür içinde bulunduğu toplumla beraber değişip dönüşsebilmektedir. Kültürlerin belirli bir dayatma olmaksızın, karşılıklı etkileşime geçmesi, toplumların kültürel yapısını olumsuz yönde etkilememekte, kültürün, çağın gereklerine göre kendiliğinden şekil kazanmasına imkân vermektedir. Buna rağmen, karşılıklılık esasına 
dayanmadan, asimetrik bir şekilde, bir kültürün diğer kültürleri etkisi altına alması yerel kültürlerin aşınmasına, yozlaşmasına ve bireylerde 'kültürel kimlik bunalımına' neden olmaktadır. Kendi kültürel değerlerine yabancılaşan bireyler, kendi kültürlerini içselleştirmek yerine içinde bulundukları 'öz' kültürleri ile ait olmayı istedikleri kültür arasında kalmaktadırlar (Mahiroğulları, 2005: 1276).

Kitle iletişim araçları, özellikle de televizyon, kültürün küreselleşmesinde önemli bir yer tutmaktadır. Televizyon, toplumdaki hemen hemen her kesime ve her yaştaki bireye hitap etmekte, bireylerin yaşam biçimleri, kültürleri ve olaylara bakış açıları üzerinde etkili olmaktadır. Türkiye İstatistik Kurumu (TÜİK) ve Radyo Televizyon Üst Kurulu (RTÜK) tarafından 2013 yılında, 06 ila 15 yaş grubu çocuklar üzerinde yapılan araştırmaya göre, bu gruptaki çocukların \% 92, 5'i, yani ortalama her 10 çocuktan 9'u her gün televizyon izlemektedir. Bu oran 06 - 10 yaş grubundaki çocuklarda \% 94, 8'dir. 06 - 10 yaş grubu çocuklarda en çok izlenen program türünü ise \% 93, 8 ile çizgi filmler oluşturmaktadır. Ayrıca aynı araştırmaya göre, aile üyelerinin birlikte yaptıkları faaliyetlerde birinci sırada \% 59, 4 ile yine televizyon izlemek geldiği görülmektedir (TUIK, 2013). Televizyon etkili bir kitle iletişim aracıdır çünkü, televizyon programlarında kullanılan görüntüler, teknolojik özelliklerin de etkisiyle, olayların düşünsel boyutlarını ikinci plana itmekte, izleyiciyi adeta olayın içine sokmaktadır (Gunter 1987: 21). Böylelikle izleyiciler, olayların neredeyse 'görgü tanığı' konumuna gelmektedirler (Powers ve Postman, 1996: 27).

Gerbner'e göre televizyon, modern toplumlarda sosyal gerçekliği inşa eden bir kitle iletişim mecrasıdır ve "tekrarlanan yaygın kalıplar yoluyla belli bir dünya görüşünü ortaya at(maktadır)" bu durum ise, ana akım "genel dünya görüşü ve değerlerini” bireylerin zihinlerine ekmektedir (Gerbner, 1972: 37'den aktaran Erdoğan, 2014: 158). Televizyon, "draması, reklamları, haberleri ve öteki programlarıla her eve bir ortak imajlar ve iletiler dünyası getir(mekte)" böylelikle "geleneksel farklılıkları, bulanıklaştır(arak), daha homojen bir ana akım içerisinde kaynaştır(maktadır)" (Erdoğan, 2014: 159). Televizyonun 'simgesel çerçevesi içerisinde doğan halk' ise televizyonun sunduğu 'tekrarlanan dersler' ile yaşamakta, böylelikle televizyon, "gelecekteki tercihleri ve kullanımları etkileyen tutumları” ekmektedir (Gerbner, 1972: 37'den aktaran Erdoğan, 2014: 159).

Gerbner (1972)'in de belirttiği gibi “izleyiciler, televizyon dünyasının kültürel dokusunda yatan anlamları emmeye eğilimlidirler" (Gerbner, 1972: 37'den aktaran Erdoğan, 2014: 160). Bu bakımdan bireylerin tutum, davranış ve tercihleri üzerinde önemli ölçüde etkileri olan televizyon içeriklerinin bilinçli bir şekilde tüketilmesi önem taşımaktadır. Buna karşın, "kitle kültürünün entegre parçası olan ebeveyn, bazen bilinçli, bazen bilinçsiz olarak televizyonu (ve çizgi film içeriğini) işlevsel bir 'dadı' olarak kullanmak(ta)", günlük işlerini gerçekleştirirken "çocukla ilgilenme işini”" televizyona bırakmaktadır. Televizyon ise çocukların boş zihinlerini işleyerek onlara "toplumun kurallarını, işleyişini ve kültürünü” aktarmaktadır (Keloğlu-İşler, 2014). Bu nedenle kitle iletişim araçlarının bireyler üzerindeki etkilerinin etraflıca değerlendirilmesi önem taşımaktadır. Bu bağlamda, gelecek nesillerin yetişmesinde ve toplumsallaşmasında etkili bir role sahip olan ve 06 - 10 yaş arasındaki çocukların sıklıkla izlediği çizgi filmler, yalnızca çocukların eğlenme, öğrenme ve hayal dünyaları ile yaratıcılıklarını geliştirme gibi ihtiyaçlarını tatmin etmemekte; bu programların kullanımı birtakım olumsuz etkileri de beraberinde getirmektedir. Bu olumsuzluklardan biri de küresel üne sahip çizgi filmlerle aktarılan Batılı kültüre ait değer ve yaşam biçimlerinin giderek yerel kültürleri etkisi altına almasidir. 
Ulus aşırı üne sahip çizgi filmleri çocukların yoğun bir şekilde tüketmesi, daha önce de belirtildiği gibi, yerel kültürlerin giderek Batılı kültürün etkisi altına girmesine, yeni nesillerin kendi kültürlerine yabancılaşmasına ve bireylerin kültürel kimlik bunalımı yaşamalarına neden olabilmektedir. Bu sebeple çizgi filmlerin sadece çocukların eğitimine ve eğlenmesine imkân veren 'masum araçlar' olarak görülmesi ve bu alanda yerel kültürlerin korunmasına yönelik çalışmaların yapılmaması gelecekte birtakım sorunları da beraberinde getirecektir. Çalışma, bu durumu bir sorunsal olarak kabul etmekte ve çizgi filmlerin çocukların zihinlerine, kültürlere ait birtakım değerleri 'ektiğini' ileri sürmektedir.

Çalışmada Türkiye'de son yıllarda üretilen Pepee, Ayas, Keloğlan ve Nasreddin Hoca gibi yerli çizgi filmler aracılığıyla küresel kültüre ait değerler karşısında, Türk kültürüne ait değer ve pratiklerin yeniden üretildiği, bu yolla da Türk kültürüne ait değerlerin çocuklar tarafından öğrenilmesine ve pekiştirilmesine katkı sağlandığı görüşü tartışılmaktadır. Bu bağlamda çalışmada, Türkiye'de en çok izlenen 'ulus aşırı üne sahip' çizgi filmlerden biri olan 'Caillou' isimli çizgi film ile yerel olarak en çok izlenen 'Pepee' isimli çizgi film, tematik analiz yönteminden faydalanılarak çözümlenmiş, küresel ve yerel kültüre ait değerlerin bu çizgi filmlerde nasıl işlendiği ve hangi kültürel değerlerin bu yolla 'ekilmeye' çalışıldığı hususu ortaya konulmuştur. Ayrıca çalışmada, 'kültürel emperyalizm' ve 'medya emperyalizmi' gibi kavramlar ele alınmış böylelikle çizgi filmlerin kültürün küreselleşmesindeki yeri ve önemi vurgulanmıştır. Okuyucuya kuramsal bir bakış açısının kazandırması hedeflenen çalışmada, Caillou ve Pepee isimli çizgi filmlerin aktardıkları değerler incelenmiş, özellikle ebeveynlere ve ailelere yönelik medya okuryazarlığının önemi vurgulanmaya çalışılmıştır. Araştırma Gerbner'in "ekme kuramı" yaklaşımı bağlamında yapılmıştır. Araştırma temel olarak çizgi filmlerin çocukların kültürel değerler edinmesinde önemli yer tuttuğu varsayımına dayanmaktadır.

\section{Küreselleşme, Kültür ve Medya,}

İngilizce'deki 'globalization' teriminden Türkçe'ye çevrilen 'küreselleşme' kavramı, gelişen iletişim teknolojilerinin de etkisiyle ve özellikle Doğu Avrupa’nın (1989) ve Sovyetler Birliği'nin (1991) çöküşünün ardından modern dünyada meydana gelen ekonomik, politik, sosyal ve kültürel değişim ve dönüşümleri açıklayabilmek için sıklıkla kullanılan bir kavram haline gelmiştir. Kavram üzerine çalışan akademisyenlerden Robertson (1992), küreselleşmeyi ‘dünyayı anlama biçimi' ve ‘dünyanın bir bütün olduğu yönünde artan algı’ şeklinde tanımlarken; Albrow ve King (1990: 8) ise, küreselleşmenin "dünya halklarını tek bir dünya toplumuna dahil eden" bütün gelişmeleri tanımlamak için kullanılan bir kavram olduğunu belirtmektedir. Fridement ise küreselleşmeyi "insanların ve piyasaların, teknolojik gelişmelerle birlikte eskisinden daha hılı, daha ucuz, daha derin bir şekilde etkileşmesi ve bütünleşmesi” olarak tanımlamıştır (Benk-Akdemir, 2004: 13). Küreselleşme kavramı mevcut literatürde genellikle ekonomik bir durum olarak ele alınırken Giddens (2013: 84)'a göre küreselleşme, ekonomik etkenlerin yanı sıra "siyasal, toplumsal ve kültürel" etkenlerin de bir araya gelmesiyle beraber ortaya çıkmıştır ve her şeyden önce, "dünyanın her tarafındaki insanlar arasındaki etkileşimin hızını ve kapsamını arttıran bilgi ve iletişim teknolojilerindeki gelişme" tarafından yönlendirilmiştir. Ona göre kavram, esasında insanların "giderek artan bir biçimde tek bir dünya içinde yaşadığg” ve "bireylerin, grupların ve ulusların birbirine bağımlı hale geldiği”" yeni bir durumu açıklamaktadır.

Marshal Mcluhan 1962 yılında yazmış olduğu "Gutenberg Galaxy” isimli eserinde, küreselleşen yeni dünya düzeni için 'global köy' kavramını kullanmış ve dünyanın iletişim teknolojilerindeki gelişmelerle birlikte 'küresel köy' haline gelmekte olduğunu 
vurgulamıştır. Erdoğan ve Alemdar (2010: 402)'a göre yeni iletişim teknolojileri sayesinde dünyanın küresel bir köye dönüştüğü fikri 1960'larda Mcluhan tarafindan ortaya atılmasına rağmen, "o zamanlar ulus kurma temeline dayanan görüş ve politikalar egemen olduğu için (bu fikir) 1980'lere kadar marjinal kal(mıştır)”. Özellikle Doğu Avrupa (1989) ile Sovyetler Birliği’nin (1991) çöküşü ve soğuk savaşın sona ermesiyle küreselleşme, tüm dünyada tartışılan bir fenomen haline gelmiştir. Mcluhan (1962: 31)'a göre iletişim teknolojilerinin etkisiyle küreselleşen dünya artık görüntü ve mesajlarla örülmüştür ve "elektro-manyetik keşifler insan ilişkilerinde simultane bir alanı yeniden yaratmış, böylelikle insan ailesi günümüzde global köyün şartları altında varlıklarını devam ettirme" durumuna gelmişlerdir. Mcluhan'ın 'global köy' ya da diğer adıyla 'küresel köy' kavramıyla açıklamaya çalıştığı küreselleşme olgu ve sürecinde medyanın ve iletişim teknolojilerinin önemli bir yeri bulunmaktadır. Buna göre nasıl ki köylerde meydana gelen gelişmeler kısa sürede köyde yaşayan bireylerin tamamına yayılabiliyorsa, iletişim teknolojilerinin, özellikle uydu sistemlerinin, televizyonun ve internet teknolojilerinin etkisiyle, dünyanın herhangi bir yerinde meydana gelen gelişmelerden artık herkes anında haberdar olabilmekte ve birbirleriyle etkileşime geçebilmektedir. Böylelikle bireyler artık küresel bir köyde yaşamaktadirlar.

Küreselleşmenin dünyadaki gelişim aşamasını beş evrede ele almak mümkündür. Bunlar, "oluşum, başlangıç, yükseliş, hegemonya için mücadele ve belirsizlik" evreleridir. Robertson'a göre iletişim araçlarının devreye girdiği son evre "küreselleşmenin kültürel boyutundaki yerinin tartışıldığı yüzyıllara denk" gelmektedir. $\mathrm{Bu}$ bağlamda küreselleşmenin kültürel boyutunu ele alan bazı düşünürler küreselleşmenin 'emperyalizmin yeni yüzü' olduğu fikrini öne sürmektedir (Robertson, 1999: 99'dan akt. Doğan, 2005: 14 - 15). Mahiroğlulları (2005: 1278)'na göre, politik güç merkezi konumundaki ülkeler artık "misyonerleri değil, iletişim araçlarını kullanarak kendi kültürlerini diğer ülke insanlarına daha kolay bir yöntemle tanıtma, yayma imkanı elde etmişlerdir". Bu durum, politik güç merkezi konumunda olan Batı'nın kültürünün "küresel kültür" adıyla "gelişmekte olan ülke kültürlerini yoğun bir şekilde etkisi altına almasına" neden olmuş, "baskın (dominant) kültür konumuna geçip ulusal kültürlerin aşınmasına" sebebiyet vermiştir. $\mathrm{Bu}$ gelişmeler kültürel emperyalizm ve medya emperyalizmi tartışmalarının da artmasına sebebiyet vermiştir.

\subsection{Kültürel Emperyalizm ve Medya Emperyalizmi Kavramları}

Küreselleşmenin ekonomiye olduğu kadar kültürel değerlere de etkisi oldukça fazladır. Esas olarak kültür; bir milletin maddi ve manevi değerleri ile o milletin yaşam biçimini yansitan bir olgudur (Mora, 2008; Göçer, 2012). Bu bakımdan medya ve iletişim teknolojilerinin etkisiyle dünyanın giderek küresel bir köye dönüşmesi ve zaman ve mekân sınırlarının iletişim teknolojileri aracılığıyla ortadan kalkması, bireylerin, toplumların ve kültürlerin birbirleri ile etkileşimlerini daha da arttırmış, bu durum kültürel değişim ve dönüşümlere hız kazandırmıştır. Küreselleşmenin etkileri ve küreselleşme sürecinde medyanın rolünü tartışan çalışmaların önemli bir kısmı "kültürel emperyalizm" ile "medya emperyalizmi" tezleri üzerinde durmakta, küreselleşmenin esasında emperyalizmin yeni yüzü olduğu görüşünü savunmaktadır.

\subsubsection{Kültürel Emperyalizm}

Kültürel emperyalizm, kavramının köklü bir geçmişi bulunmamaktadır. Kavram, 'radikal eleştirinin' diğer terimleri gibi 1960'larda ortaya çıkmış ve yirminci yüzyılın ikinci yarısının genel entelektüel düşüncesinin bir parçası konumuna gelmiş (Tomlinson, 1999: 13), Herbert Schiller, Dallas Smythe ve Armand Mattelard gibi akademisyenler tarafindan 
da yaygınlaştırılmıştır (Erdoğan ve Alemdar, 2010: 381). Benarjee (2002: 519), kültürel emperyalizm kavramı ile "medya ürün ve hizmetlerinin ilerlemiş sanayi ülkelerinden 'Üçüncü Dünya' ülkelerine doğru tek yönlü aktığını ve bu ülkelerin kültür, ahlak ve değerlerini zayıflattığı” görüşünü ileri sürmektedir. Bu anlayışa göre:

Uluslararası ilişkilerde, transfer edilen teknolojik araç ve ürünlerin doğal olarak ekonomik ve kültürel sonuçları olacaktır. Teknolojik araçların transferi demek, örgüt yapılarının, profesyonel iş kültürünün değerlerin ve ideolojilerin de transferi demektedir. Bu transfer, uluslararası ve ulusal sermayenin birbirleriyle ve devlet kurumlarıyla (özellikle hükümet ve orduyla) olan ilişkilerinin sonucu gerçekleşir. Transferle oluşan üretimle, ürün içeriğini doldurma ve dolaşıma sokma sonucunda, küresel ve yerel endüstriyel yapıların çıkarına uygun, siyasal, ekonomik bilinç yapıları oluşturulur ve desteklenir. Bu oluşturma ve desteklemeyle getirilen egemenlik koşulunda, yerel kültürel pratiklerin ve kültürlerin bir kısmı yok edilir, bir kısmı dönüştürülerek kullanılır ve bir kısmı da değersizleştirilerek marjinal hale getirilir. Buna kültürel emperyalizm denir (Erdoğan ve Alemdar, 2010: 381).

$\mathrm{Bu}$ doğrultuda kültürel emperyalizm, devletlerin ve kültürlerin etkileşiminde siyaset, ekonomi ve teknoloji bakımından daha gelişmiş konumdaki ülkelerin, medya ile teknolojik araç ve ürünler yoluyla diğer ülkeleri etki altına alması durumuna işaret etmektedir. Kültürel emperyalizm tezi, mevcut literatürde sıklıkla yerel kültürlerin Amerikan kültürünün etkisi altında kalması ile özdeşleştirilmekte, "dünyanın pek çok yerinde otantik, geleneksel ve yerel kültürlerin özellikle Amerika Birleşik Devletleri (ABD)'nin ticari ürünler ve medya ürünleri bombardımanı dolayısıyla yok edildiğini” belirtmek için kullanılmaktadır (Tomlinson, 1999: 22). Hall, "küresel kitle kültürü, Batı merkezlidir ve daima İngilizce konuşur” (1998: 49'dan akt. Akça, 2008) diyerek esasında günümüzde küresel kitle kültürünün Amerikan/Batı kültürünün etkisi altında kaldığını ileri sürmektedir. $\mathrm{Bu}$ bakımdan küresel kitle kültürü Amerikan/Bat1 kültürünün etkisi altında homojenleşmekte, tek tipleşmekte ve standartlaşmaktadır.

Kültür emperyalizmi ya da kültürel emperyalizm kavramı esasında Frankfurt Okulu düşünürlerinin ileri sürdükleri 'kültür endüstrisi' kavramıyla ilişkili bir kavramdır. Frankfurt Okulu'nun önde gelen düşünürlerinden Max Horkheimer ve Theodor Adorno'nun kitle kültürü kavramı yerine kültür endüstrisi kavramını kullanmalarıyla bu kavram, okulun genel görüşlerini ifade eden ana kavramlardan biri haline gelmiştir. $\mathrm{Bu}$ düşünürlere göre kültür endüstrisi, "kitle iletişiminin bir iş/ticaret olduğunu ve ekonomik ve siyasal güçler tarafından ve güçlülerin çıkarları için kültür propagandası yaptığını açıkça ima” etmektedir (Erdoğan, 2014: 273). Bu düşünürlere göre medya, kültür endüstrisinin bir propoganda aracıdır ve kültür endüstrisini elinde bulunduran kesimler kendi çıkarları doğrultusunda kültürel ürünleri üretmektedir. Burada dikkat edilmesi gereken husus, kültür endüstrisi tarafından üretilen kültüre, kitlelerin katkısının düşük düzeyde olmasıdır.

Kültür endüstrisi anlayışına göre, modern kapitalist toplumlarda kültürün kendisi bir endüstri konumuna getirilmekte ve kültürel değerler bu endüstri tarafından metaya dönüştürülerek ekonomik, siyasi ve teknolojik bakımdan güçsüz ülkelere dayatılmaktadır. Frankfurt Okulu düşünürlerine göre, kültür endüstrüleri eğlence firmaları ve medyadır. Medyanın kültürün küreselleşmesinde ve Batılı kültür doğrultusunda homojenleşmesinde önemli işlevleri bulunmaktadır. Herbert Schiller'in de belirttiği gibi medya modern toplumlarda "ekonomik işlevlerinin yanında ideolojik bir araçtır ve toplumu manipüle ederek zihinleri yönlendirmekte ve topluma paketlenmiş bilinç sunmaktadır" (Yaylagül, 2010: 160). 
Geleneksel olarak bireyleri bilinçlendirme, toplumsallaştırma ve bireylere kültürel değerleri aktarma gibi görevleri aile üstlenmiştir. Buna karşın, modern toplumlarda aile önemini ve işlevlerini giderek kaybetmektedir. Aile, giderek bilinçlendirme, toplumsallaştırma ve bireylere kültürel değerleri aktarma gibi görevlerini "kültür endüstrilerine" yani medyaya ve eğlence şirketlerine bırakmaktadır. Schiller gibi Frankfurt okulu düşünürlerinden Adorno ve Horkheimer da kitle iletişim araçlarının baskıcı bir yapıda olduğunu düşünmektedir. Onlara göre medya ve kültür endüstrileri, "gittikçe egemen bir konuma" gelmekte ve "geleneksel olarak toplumsallaşma kurumlarının yerine almaktadır". Bu düşünürlere göre modern kapitalist toplumlarda, kültür ve sanat eserleri endüstriyel olarak üretilir, fakat bu "imalat sürecinde standart ve yaratıcılıktan uzak bir iş bölümü vardır. Nihai ürün standarttır, önceden tasarlanmıştır ve özgünlük içermez”. Bu durumun nedeni bu ürünlerin "izleyicilerin en düşük ortak paydasına" hitap etmesidir. Sonuç olarak kültür endüstrileri tarafından üretilen ürünler "var olan düzenle bütünleştirici, tüketime yönelik, bireysel olarak çalışma ve sınıf atlama yönünde" mesajlar vermekte, bu yolla da mevcut düzenin "yeniden üretilmesini”" sağlamaktadırlar (Yaylagül, 2010: 161).

Schiller'e göre ise kültürel emperyalizm, genel emperyalizm sisteminin 'bir alt tezi' konumundadır çünkü, kültürel ve ekonomik alanlar birbirlerinden ayırt edilemezler. $\mathrm{Bu}$ nedenle kültürel değerlerin medya ve kültür endüstrileri tarafindan üretilmesi sonucunda ortaya çıkan "kültürel çıktı (ürün) olarak nitelenen şey, aynı zamanda ideolojiktir ve sistemin çıkarına hizmettir" (Schiller, 1991'den aktaran Erdoğan ve Alemdar, 2010: 386). Mattelart (1992) gibi bazı düşünürler, kültürel emperyalizm tezinin özellikle 1980'lerden sonra anlamını yitirdiğini ileri sürmektedir. Buna göre, "kültürel emperyalizm tezinin 'metropol-periferi' ikilemi içinde sunulması, bağımlı ülkelerdeki iç sömürü yapısının göz önüne alınmaması, kültürel ırkçılığa yönelimi ve kültürün ekonominin önüne ko(nulması)” bu tezin önemini kaybetmesine sebebiyet vermiştir. 1990'larda bu konu etrafindaki çalışmalar, kültürel bağımlılık anlayışı yerine; karşılıklı bağımlılık ya da eşit olmayan asimetrik karşılıklı bağımlılık anlayışı üzerinde durmuşlardır (Erdoğan ve Alemdar, 2010: 378).

\subsubsection{Medya Emperyalizmi}

Amerika Birleşik Devletleri başta olmak üzere sanayileşmiş Batılı ülkelerin medya üretimi Herman ve McChesney gibi birçok araştırmacının dikkatini medya emperyalizmi kavramına çekmiştir. Bu anlayışa göre günümüzde medya aracılığıyla bir kültür imparatorluğu inşa edilmektedir ve "az gelişmiş ülkeler kendi kültürel bağımsızlıklarını sağlayacak kaynaktan yoksun oldukları için özellikle saldırıya maruz kalmaktadırlar" (Giddens, 2013: 672). 1970'li yıllarla beraber ortaya çıkan ve yaygınlaşan medya emperyalizmi tezi Oliver Boyd-Barret tarafından ortaya atılmıştır. Bu teze göre, medya emperyalizmi, "herhangi bir ülkedeki medya sahipliği, yapısı, dağıtım veya içeriğinin tek başına veya birlikte, diğer ülke veya ülkelerin medya çıkarlarının önemli miktarda dış baskısına maruz kalması sürecidir" (Erdoğan ve Alemdar, 2010: 378). Buna göre, gelişmiş ülkelerdeki egemen kültür ve değerler medya aracılığıyla gelişmekte olan ülkelere empoze edilmektedir. Medya, genellikle gelişmiş Batılı ülkelerin egemenliği altında olduğu için bu kültürlere ait değerler, medya aracılığıyla ve bilinçli bir şekilde Üçüncü Dünya Ülkeleri'ne taşınmakta, böylelikle yerel kültürlere ait değerler aşındırılmaktadır. Batılı kültüre ait değerlerin medyadaki standartlaştırılmış yansımasına maruz kalan bireyler, kendi değerlerine ve kültürlerine yabancılaşmaktadır.

Bilindiği üzere dünyanın en büyük medya şirketleri Batılı, çoğunlukla da Amerikan kökenlidir. AOL-Time Warner, Disney ABC ve Viacom gibi medya imparatorluklarının 
tamamı Amerika Birleşik Devletleri'nde yer almaktadır. Ayrıca, diğer büyük medya holdingleri de gelişmiş Batılı ülkelerde bulunmaktadır. Bunlardan CBS Records ve Columbia Pictures'ın mülkiyet sahibi bir Japon şirketiyken; RCA Records ve A.B.D. kaynaklı bir dizi basım şirketinin sahibi ise Alman Bertellesmann şirketidir. Mandadore isimli medya şirketi ise eski İtalya Başbakanı ve dünyanın en zengin kırk kişinden biri olan Silvio Berlusconi'nin sahibi olduğu bir şirkettir (Giddens, 2013: 672). Görüldüğü üzere gelişmiş Batılı şirketler küresel medya organlarını ellerinde bulundurmakta ve bu medya organları aracılığıyla üretilen yoğunluklu olarak Batı kültürüne ait içerik ve değerler diğer toplumlara aktarılmaktadır.

Erdoğan ve Alemdar (2010: 378)'a göre uluslararası medya sahipliği, kitle iletişiminde akla gelebilecek her alana yayılmaktadır. "Bu yayılma, telekomünikasyon, cep telefonu ve diğer ilgili endüstrilere doğru genişlemektedir. Ülkelerde dil ve kültür giderek, küresel pazarın diline ve kültürüne (ideolojisine) bütünleşmektedir. Medya endüstrileri üretimden tüketime kadar olan tüm süreçleri kontrol etmektedir”. Giddens (2013: 672)'a göre de yeni medya alanında meydana gelen gelişmeler medya emperyalizminin artarak devam etmesine sebebiyet vermekte, "elektronik medya sayesinde Batılı kültür ürünleri tüm dünyayı kapsayacak şekilde yaygınlaşmaktadır”. Bu durum, kültür emperyalizmi tezinde olduğu gibi, özellikle Üçüncü Dünya ülkelerinin kültürlerini tehdit etmektedir (Tomlinson 1999: 60).

Medya teknolojilerinin yaygınlaşması farklı kültürlerin etkileşime geçmesine imkân vermekte, kültürel etkileşimi hızlandırmaktadır. Ancak, bu kültürel etkileşim karşılıklı gibi görünse de, iki yönlü fakat 'asimetrik' bir yapıya sahiptir. Şöyle ki küresel medya şirketlerini elinde bulunduran gelişmiş Batılı ülkeler, Batı kültürüne ait değerleri bu medya organları aracılığıyla yoğun bir şekilde diğer ülkelere aktarmaktadır. Burada niceliksel, teknolojik ve ekonomik üstünlük bu ülkelerde olduğu için bilgi ve enformasyon akışının 'yoğunluğu' Batı lehine işlemektedir. Böylelikle ekonomisi, siyaseti ve teknolojisiyle üstün konumda olan Batılı ülkelere ait değerler ve kültürel unsurlar, bu imkânlara sahip olmayan diğer ülke toplumlarını kolaylıkla etkilemektedir. Bu durum, dünyadaki bütün kültürlerin küreselleşmesine değil sadece belli kültürlerin küreselleşmesine imkân vermektedir. Bunun sonucunda ise, kültürel çoğulculuk yerine 'kültürel difüzyon' ya da 'kültür emperyalizmi' gibi durumlar ortaya çıkmaktadır. Bu durumdan en çok etkilenenler ise, medya iletilerine yoğunlukla maruz kalan çocuklar olmaktadır. Bu nedenle yerel kültürlerin korunabilmesi, yeni nesillere aktarılabilmesi ve kültür emperyalizmi ya da medya emperyalizmi gibi bireylerin kendi kültürlerine yabancılaşmasına neden olabilecek durumların engellenebilmesi için, yerel düzeyde birtakım stratejik iletişim çalışmaları yürütülmelidir.

\section{2. Çizgi Filmlerin Kültür Aktarımında Yeri ve Önemi}

Bir toplumun kültürel mirası, "kulaktan kulağa veya kuşaktan kuşağa aktarılarak üretilen, yaşatılan ve gelecek kuşaklara devredilen canlı bir mirastır” (Oğuz, 2009: 63). Bu mirasın gelecek kuşaklara aktarılmasında önemli unsurların başında aile ve çocuklar gelmektedir. Geleneksel olarak çocuklara dış dünyayı algılamaya başladıkları andan itibaren ebeveynleri tarafından içinde yaşanılan toplumun kültürü ve yaşam tarzı hakkında bilgiler aktarılmaktadır. Ardından ise oyun ve arkadaş grupları, eğitim kurumları, dini kurumlar, kitle iletişim araçları ile sanat ve edebiyat eserleri aracılığıyla çocuklara kültür aktarımı yapılarak, onların toplumsallaşması sağlanmaktadır (Öğüt, 2010: 2). Buna karşın modern toplumlarda aile, giderek bireyleri bilinçlendirme, toplumsallaştırma ve kültürel değerleri aktarma gibi işlevlerini kaybetmekte, bu görevlerini "kültür endüstrilerine" yani medyaya ve eğlence şirketlerine bırakmaktadır. Kültür endüstrileri, "gittikçe egemen bir 
konuma" gelmekte ve "geleneksel olarak toplumsallaşma kurumlarının yerini almaktadır" (Yaylagül, 2010: 161). Bu nedenle kitle iletişim araçlarının bireyler üzerindeki etkilerinin etraflıca değerlendirilmesi elzemdir. Bu bağlamda, gelecek nesillerin yetişmesinde etkili bir role sahip olan ve 06 - 10 yaş arasındaki çocukların sıklıkla izlediği çizgi filmler, yalnızca çocukların eğlenme, öğrenme ve hayal dünyaları ile yaratıcılıklarını geliştirme gibi ihtiyaçlarını tatmin etmemekte, bu programların kullanımı birtakım olumsuz etkileri de beraberinde getirmektedir. Bu olumsuzluklardan biri de küresel üne sahip çizgi filmlerle aktarılan Batılı kültüre ait değer ve yaşam biçimlerinin giderek yerel kültürleri etkisi altına almasidir.

Giroux (1999: 84)'un da ifade ettiği gibi çocukların büyük ilgi gösterdiği çizgi filmlerin eğlenmenin ötesinde birtakım toplumsal ve kültürel işlevleri de vardır. Hatta yazara göre bu işlevler "aile, okul ya da dini kurumlardan daha güçlü” konumdadır ve bu geleneksel toplumsallaştırıcı kurumlara göre daha fazla "kültürel yetki ve meşruiyet" taşımaktadır. Ker-Dincer ve Yılmazkol (2009: 194)'a göre de çocuklar televizyon ve çizgi filmlerden son derece etkilenmektedir. Yazarlara göre bu durumun nedeni çocukların "görsel ağırlıklı bir dünyaya doğmalarıdır". Bu sebeple çocuklar, "görselliğin temel oluşturduğu televizyondan", "okul, aile ve çevre(ye)" göre daha fazla etkilenmekte, televizyon tarafından sunulan "duygu, davranış, tutum, öğrenme kalıpları" ile "hayatı anlamlandırmaya çalış(maktadırlar)”. Benzeri bir şekilde Walt Disney isimli dünyaca ünlü eğlence firmasının kurucusu Walt Disney, "bir çocuğun beyninin boş bir defter olduğunu düşünürüm. Hayatlarının ilk yıllarında bu defterin sayfalarına çok şey yazılır. Bu yazıların kalitesi onun yaşamını derinden etkileyecektir" diyerek çizgi filmlerde aktarılacak içeriklerin ve değerlerin önemine dikkat çekmektedir (Akt. Giroux, 1999: 17). Bu nedenledir ki, gelişmiş Batılı ülkelerde çocuklara aktarılan kültür yetişkinler tarafından üretilmekte, çocuklar kitap, dergi, televizyon, müzik, bilgisayar, spor, oyuncaklar ve giyim, televizyon ve film gibi araçlar yoluyla kontrol altında tutulmaktadır (Marsh ve Millard, 2000, 20 - 21'den akt. Terkan, 2011: 10).

Atan (1995: 4)'ın da belirttiği gibi çizgi filmler zaman zaman "milletler arası" siyasi ve kültürel bir "propaganda aracı" olarak da kullanılabilmekte ve "çizgi filmlerin bu türü yurdu sosyo-kültürel açıdan tehdit edebilmektedir”. Çizgi filmlerin bir tür propaganda aracı olarak kullanılmasına 1930'larda Amerika da sigaranın zararlarının anlaşılması ile başlatılan "Miki Fare sigara içmez, içki kullanmaz, sahtekarlık yapmaz ve yalan söylemez..." propagandası gösterilebilir. Ayrıca Red Kit'in "bir zamanlar ağzından eksik olmayan sigarası, sigara içmenin kötülüklerinin artık iyice anlaşılması ve benimsenmesinden sonra bir saman çöpüne dönüştürülmüştür. Böylece hem izleyen sigaraya özenmemiş olur, hem de Red Kit evrensel olarak yürütülen anti sigara kampanyasına karşı bir tutum" sergilenir (Kongar, 1986: 83'ten akt. Güler, 2013: 210).

Görüldüğü üzere çizgi filmler hem bir propaganda aracı hem de gelecek nesillerin yetiştirilebilmesi ve yerel kültürel değerlerin korunabilmesi bakımından bir tür kültürel aktarım aracı olarak kullanılabilmektedir. Gelişmiş Batılı ülkelerde nitelik ve nicelik açısından güçlü medya şirketleri bulunmakta, bu şirketler tarafından ulus aşırı üne sahip çizgi filmler üretilerek Üçüncü Dünya ülkelerinde yayınlatılmaktadır. Bu tür ulus aşırı üne sahip çizgi filmler, Batılı kültürel değerlerin ve yaşam tarzlarının diğer ülkelerde yaygınlaşmasına ve Batı kültürünün küreselleşmesine imkân vermektedir.

Yakın zamana kadar çizgi film sektöründe Türk firmalarının etkili bir şekilde yer almaması Türk çocuklarının farklı kültürlerin etkisi altına girmesine sebebiyet vermiştir (Türkmen, 2012: 139). Atan (1995: 2)'nn da belirttiği gibi kendi teknolojisini, kültürünü ve 
ideolojisini üretemeyen toplumlar, yabancıların ürettiği teknoloji ve dolayısıyla da kültür ve ideolojiyi de benimsemek durumunda kalır. Bu bakımdan Türk kültürüne ve yaşam tarzına ait kodlar taşıyan çizgi filmlerin üretilmesi önem arz etmektedir. Bununla beraber kültür alanı daima bir mücadele alanıdır. Kültür alanını "bir çeşit daimi savaş alanı kılan direniş ve kabul etme, reddetme ve teslim olma gibi unsurlar sürekli olarak devam etmektedir". Bu bir tür "kültürel mücadelenin diyalektiğidir" (Hall, 1981: 233'den aktaran Terkan, 2011: 10). Bu bakımdan çizgi filmleri bir tür kültürel mücadele alanı olarak görmek mümkündür.

\section{Pepee ve Caillou İsimli Çizgi Filmlerin Taşıdığı Kültürel}

\section{Kodların İncelenmesi}

Son y1llarda Türkiye'de üretilen Pepee, Ayas, Keloğlan ve Nasreddin Hoca gibi yerli çizgi filmler, küresel kültüre ait değerler karşısında, Türk kültürüne ait değer ve pratikleri yeniden üretmekte, bu yolla da Türk kültürüne ait değerlerin çocuklar tarafından öğrenilmesine ve pekiştirilmesine katkı sağlamaktadır. Buna karşın Türkiye'de halen ulus aşırı üne sahip çizgi filmlerin ve bu filmlerin taşıdığı kültürel kodların etkili olduğunu söylemek mümkündür. Bu bakımdan kültürel mücadele alanı olan çizgi filmlerde yerli yapımların arttırılması önem taşımaktadır. Çalışmanın devam eden kısmında Türkiye'de en çok izlenen 'ulus aşırı üne sahip' çizgi filmlerden biri olan "Caillou” isimli çizgi film ile yerel olarak en çok izlenen "Pepee" isimli çizgi filmin aktardıkları değerler analiz edilecek böylelikle çizgi filmlerin bir tür kültürel mücadele alanı olduğu düşüncesi desteklenecektir.

\subsection{Amaç ve Önem}

Mevcut literatürde yabancı medya organları tarafindan üretilen televizyon programlarının, animasyonların, çizgi filmlerin ve sinema filmlerinin çocukların ana dillerini, kültürlerini ve geleneklerini öğrenmelerini olumsuz yönde etkilediğini gösteren çalışmalar bulunmaktadır (Çilingir, 2014: 147). Ayrıca televizyonun yetişkinlere nazaran çocukların gelişimi üzerinde olumlu ve olumsuz birtakım etkilerinin olduğunu belirten çalışmaları da literatürde görmek mümkündür (Akçalı, 2007; Türkmen, 2012). Bunun yanı sıra küreselleşmeye karşı Somut Olmayan Kültürel Miras (SOKÜM)'ın korunması hususu da UNECO tarafından hazırlanan SOKÜM sözleşmesi ile resmileşmiştir. ${ }^{1}$ Buna karşın televizyon programlarının ve çizgi filmlerin kültürel etkileri hususunda hem izleyicilerde hem de yöneticilerde yeterli bir farkındalık düzeyi bulunduğunu söylemek mümkün değildir (Türkmen, 2012: 143).

Walt Disney'in de belirttiği gibi 'çocukların zihinleri bir boş bir levha gibidir' ve onların zihinlerine hayatlarının ilk dönemlerinde yerleştirilen düşünce ve yaşam tarzları onların gelecekteki yaşamlarını son derece etkileyecektir. Bu nedenle çalışma konu ile ilgili farkındalık yaratmaya çalışması ve mevcut bilgi birikimine katkı sağlaması bakımından önem taşımaktadır. Bu doğrultuda çalışmanın temel amacı, kültürün küreselleşmesinde önemli bir etken olan çizgi filmler hakkında bir farkındalık yaratmak ve aileler ile yetkili kurumlara yerel kültürlerin korunması ve medya okur yazarlığı bağlamında birtakım önerilerde bulunmaktır.

\subsection{Yöntem}

Çalışma yukarıda belirtilen amaç doğrultusunda, Türkiye'de en çok izlenen ulus aşırı üne sahip çizgi filmlerden biri olan "Caillou” isimli çizgi film ile yerel olarak en çok

${ }^{1}$ SOKÜM sözleşmesi hakkında ayrıntılı bilgi edinmek için Öcal (2009) ve Türkmen (2012)'nin yaptığ çalışmalar incelenebilir. 
izlenen çizgi filmlerden biri olan "Pepee" isimli çizgi filmi örneklem grubu olarak ele almıştır. Çalışmada tematik analiz yönteminden faydalanılarak küresel ve yerel kültüre ait değerlerin bu çizgi filmlerde nasıl işlendiği ve hangi kültürel değerlerin bu çizgi filmlerde işlendiği hususu ortaya konulmaya çalışılmıştır. İncelenen çizgi filmlerde hangi anahtar temaların nasıl geliştirildiğini görmek ve söylemin yoğunlukla hangi temalar etrafinda geliştirildiğine ilişkin ipuçları elde etmek amacıyla (Dursun, 2001: 203) çalışmada tematik analizden yararlanılmış, çizgi filmin senaryosu ve filmde geçen diyaloglar görsel malzeme ile birlikte değerlendirilmiştir. Bu doğrultuda adı geçen çizgi filmler izlenerek bu çizgi filmlerle aktarılan kültürel değerler aile, dil ve hitap şekilleri ile aktarılan değerler, yaşam biçimi, kıyafet ve aksesuarlarla aktarılan değerler, yemekler ve mutfak kültürü ile aktarılan değerler, danslar, halk oyunları ve şarkılarla aktarılan değerler, çocuk oyunları ile inanç ve milli hassasiyetler ile aktarılan değerler başlıkları altında 7 kategoriye ayrılmıştır. Bu ayrım yapılmadan önce mevcut literatürde konu ile ilgili yapılan çalışmalar örnek alınmıştır (Türkmen, 2012; Yorulmaz, 2013a ve Yorulmaz, 2013b). Bu kategoriler altında çocuklara aktarılan değerler ve bu değerlerin neler olduğu incelenmiştir.

Çalışmada araştırma konusu olan Caillou ve Pepee isimli çizgi filmlerin sistematik örnekleme yöntemi ile seçilen bölümleri incelenmiştir. Bu doğrultuda Pepee isimli çizgi film için, TRT çocuk kanalının resmi sitesinde (www.trt.tv) de yer alan 82 çizgi film videosundan 10 tanesi, Show TV'nin resmi sitesinde yer alan (www.showtv.com) 28 videodan ise 3 tanesi, her 10 videodan birinin incelenmesi koşuluyla rastgele seçilerek incelenmiştir. Aynı şekilde Caillou isimli çizgi filmin yayıncılarından olan Yumurcak TV'ye ait videoların yer aldığı www.küretv.com isimli sitede yer alan 300 videodan da 30 tanesi, yine her 10 bölümden bir tanesinin izlenmesi koşuluyla, rastgele seçilerek tematik söylem analizi yöntemiyle incelenmiştir. Çalışmanın analiz kısmına geçilmeden önce Pepee ve Caillou isimli çizgi filmlere ait bazı temel bilgilerin verilmesi çalışmanın daha iyi anlaşılması bakımından önem taşımaktadır.

\subsection{Pepee ve Caillou Hakkında:}

\subsubsection{Pepee}

Düşyeri Çizgi Film Stüdyosu tarafından hazırlanan ve Ayşe Şule Bilgiç tarafından yapılan Pepee isimli çizgi film, 6 Haziran 2008 yılında TRT Çocuk kanalında yayın hayatına başlamış, Show TV ve Planet Çocuk isimli kanallarda da yayınlanmıştır. Pepee, 3 ila 6 yaş grubundaki çocuklara hitap eden bir çizgi filmdir. Çizgi filmin ana karakterinin adının Pepee olmasını Ayşe Şule Bilgiç Haber Türk’te yaptığı bir röportajında şu şekilde açıklamaktadır, "Pepee öz Türkçe pepemeden geliyor. İlk konseptimizde Pepee konuşma zorluğu çeken bir çocuktu ve diş ses yardımıyla daha iyi konuşmayı öğreniyordu. Buna uygun bir isim olsun istedim. Diğerlerini de (Bebe, Şuşu, Şila, Maymuş, Zuku vs.) yaş grubuna sıcak gelecek, kolay söylenecek ve çağrışımı olmayan hecelerden seçtim”. Bilgiç aynı röportajında Pepee'nin bu kadar çok sevilmesinin nedenini şu şekilde açıklamaktadır, "çünkü (Pepee) ideal bir çocuk portresi çizmiyor. En büyük farkı da bu. O olması gereken anlamda ideal çocuk, yani sevgi dolu, soran, sorgulayan, merak eden ama aynı zamanda hata da yapabilen..." (Erbaş, 2012, Haziran 3). Her bölümünün yaklaşık 7 ila 11 dakika arasında sürdüğü animasyon çizgi filmin diğer karakterleri arasında Pepe'nin annesi, babası, dedesi, ninesi, kız kardeşi bebe ve Şuşu (dış ses) ile, Zulu (bir zürafa), Maymuş (bir maymun), Köpüş (bir köpek)'ün yanı sıra bölümlerin içeriğine göre yer alan kurbağa, inek vb. gibi hayvanlar yer almaktadır. Çizgi filme yayınlanmasından yaklaşı 3 yıl sonra teyze ve enişte gibi yeni akraba karakterler de eklenmiştir (Türkmen, 2012: 144). 


\subsubsection{Caillou}

Fansız yazar Christine L'Heureux ve çizer Hélène Desputaux'nun çalışmaları sonucu ortaya çıkan Caillou, ya da Türkçe okunuşuyla Kayu, 2 ila 6 yaş grubundaki çocuklara hitap eden bir çizgi kahramandır. Caillou, Kanada'da yayınlanan kitap serisinin ardından İsviçre'den Dubai'ye, Almanya'dan İspanya'ya kadar ellinin üzerinde ülkede yayınlanmaktadır (Yavuz, 2011, Mayıs 18). Fransızca'da 'çakıl taşı' anlamına gelen 'caillou' kelimesi "saçsız baş" anlamında da kullanılmaktadır. Caillou karakterinin dizide saçı yoktur. Yapımcıların konu hakkındaki yorumları resmi sitede şöyledir "kitaptaki Caillou karakterinin yaşı, dizidekinden daha küçük. Bebeklerin saçları da gür değil. Dizi için yapılan yuvarlamada da aslı bozulmadı ve bu yüzden yaşı büyümesine karşın Caillou karakteri televizyona saçsız olarak aktarıldı" (Araslı ve Pilgir, 2010, Aralık 20). Çizgi filmdeki diğer karakterler, Caillou'nun annesi Doris, babası Boris, kız kardeşi Rozi, Caillou'nun büyükannesi ve büyükbabası ile kedisi Gilbert'dir. Bunun yanı sıra çizgi filmin karakterleri arasında Clementine, Sarah, Xavier, Emma, Leo ile pizza yemeği çok seven Jason \& Jeffrey isimli ikizler bulunmaktadır. Çizgi filmde sık geçen karakterlerden biri olan bayan Martin ise Caillou'nun öğretmenidir. Çizgi filmde her bölüm yaklaşık 3 ila 8 dakika uzunluğundadır.

\subsection{Pepee ve Caillou'de aktarılan kültürel değerler}

Çalışmanın bu kısmında Pepee ve Caillou isimli çizgi filmlerle aktarılan kültürel değerlerin neler olduğu çalışmada çeşitli temalar altında incelenecektir.

\subsubsection{Pepee ve Caillou'da Aile ile ilgili Aktarılan Değerlerin Karşılaştırılması}

Kültürün devingen bir yapısı bulunmakta, içinde bulunduğu toplumla beraber değişip dönüşebilme özelliği göstermektedir. Kültürü oluşturan, onu yaşatan ve gelecek nesillere aktaran insan ve insan topluluklarıdır. İnsanlar kendi kültürlerini ve yaşam biçimlerini yeni nesillere, dil aracılığıyla aktarmaktadırlar. Kültürün yaşatılması ve gelecek nesillere aktarılması hususunda ailenin de çok önemli bir görevi bulunmaktadır. Aile, yeni doğan insan yavrusuna, içinde yaşadığ 1 toplumun dilini, yaşam tarzını ve kültürünü öğreterek onu toplumsallaştırmakta, topluma ait kıymet hükümlerini, hayat görüşlerini, örf ve adetleri yeni nesillere aktarmaktadır. Bu bilgiler doğrultusunda Pepee ve Caillou isimli çizgi filmler incelendiğinde, belirtilen çizgi filmlerdeki aile yapısı ve ilişkilerinin farklılık gösterdiğini söylemek mümkündür.

Öncelikle belirtmek gerekirse Pepee isimli çizgi film Türk kültüründen ve yaşam tarzından büyük izler taşımakta, çizgi filmin baş karakteri ve diğer karakterler Türk olduklarını izleyiciye daima hissettirmektedirler. Bu durumu Pepee'nin aile yapısında da görmek mümkündür. Pepee anne, baba, bebe (k1z kardeş), dede, nene ile teyze, enişte ve kuzenlerden (Şila ve Eke) oluşan geniş bir ailede yaşamakta, günlük zamanının önemli bir kısmını yakın akrabalarıyla geçirmektedir. Piknik, gezi, kutlama gibi birçok etkinlik, halk oyunları ve danslarda da geniş ailenin fertlerinin birlikte, kollektif olarak hareket ettiklerini görmek mümkündür. Pepee'nin anne ve babası gün içinde evde olmadığından Pepee'ye birçok Türk ailesinde olduğu gibi dedesi ve ninesi bakmaktadır. Çizgi filmde Pepee'nin dedesi, Türk toplumunda sıklıkla görülebilecek özellikleri şekil ve tavırlar bakımından taşımaktadır. Dede, bıyıklı ve güleç yüzlü klasik bir dede figürü iken, nene de başörtülü ve gözlüklü, konuşma biçimiyle de Türk toplumunda sıkça karşılaşılabilecek bir nine profili çizmektedir. Pepee, dedesini ve nenesi çok sevmekte, onlarla vakit geçirmekten mutluluk duymaktadır. Hatta Pepee, nenesini ve dedesini mutlu etmek ve onları çok sevdiğini belirtmek için çeşitli halk oyunları ve şarkılar öğrenerek onların aile içinde önemli birer fert 
olduğunu hissettirmektedir. Dedesi, Pepee ile oyunlar oynamakta, ona çok sevdiği tahta misketler yapmakta, nenesi ise Pepee ile masallar okumakta, çok sevdiği patatesli gözlemenin hamurunu merdane ile açarak bahçede sac üzerinde pişirmektedir. Aile içi ilişkiler oldukça samimi ve içtendir. Nene torunlarını severken "kaçmayın sizi biraz mıncıklayacağım", dedesi ise sıklıkla "sizi gidi keratalar" gibi sözler söylemektedir. Ayrıca Pepee, Şila ve Bebe enişteleri ve teyzelerini mutlu etmek için, onların evlilik yıl dönümlerinde sürpriz yaparak en sevdikleri oyun olan "Çayda Çıra" oyununu oynamaktadırlar. Pepee'nin annesi ise pikniğe götürülecek eşyalarını toparlarken, "ah insanın güzel ve kalabalık bir aileye sahip olması ne güzel” diyerek geniş ailenin güzelliklerinden bahseder.

Caillou'nun ailesi ise Batılı ülkelerde olduğu gibi çekirdek bir aileden oluşmaktadır. Aile, Caillou, annesi Doris, Babası Boris ve kız kardeşi Rozi'den oluşmaktadır. Caillou ve Rozi, büyükannesi ve büyükbabasını karşılıklı olarak sıklıkla ziyaret etmekte, birlikte kutlamalar gibi çeşitli etkinlikler yapmaktadır. Buna karşın büyükanne ve büyükbabanın dışında ailenin diğer fertleri hakkında herhangi bir bilgi verilmemektedir. Öte yandan Pepee'nin ninesi geleneksel görünümlü ve başörtülü tonton bir nine, dedesi de bıyıklı ve bilge bir dede iken, Caillou'nun büyükannesi ve büyükbabası modern görünümlü bireylerdir. Caillou'nun büyükbabası sportmen bir yapıya sahip olmakla beraber zaman zaman Caillou ve arkadaşlarına koçluk yapmakta, Caillou ile beysbol ve kroket gibi Türk toplumunda pek de yaygın olmayan oyunlar oynamaktadır. Ancak aralarındaki ilişki Pepenin dedesiyle olan ilişkisine göre daha resmi, zaman zaman da kuralcı olabilmektedir. Bunun yanında Pepee'de olduğu gibi enişte, teyze kuzen gibi diğer akrabalara rastlamak mümkün değildir. Bu doğrultuda Caillou'da modern Batılı aile yapısının yansıtılmakta olduğunu ve Batılı aile tipine ait değerlerin aktarıldığını söylemek mümkündür.

\subsubsection{Kullanılan Dil ve Hitap Şekillerinin Karşılaştırılması}

Türk kültürünün izlerinin sıklıkla görüldüğü Pepee'de, ele alınan konuların yanı sıra aile içi ilişkiler, kullanılan dil ve hitap biçimleri de, Türk toplumunun günlük yaşamından izler taşımaktadır. Pepee, dede ve ninesine seslenirken büyükanne ve büyükbaba sözcüklerini tercih etmemekte, bunun yerine günlük yaşamda sıkça kullanılan "dede" ve “nene” sözcüklerini kullanmaktadır. Pepee’nin kız kardeşi Bebe, Pepee’ye hitap ederken "abi" yada "abiş" kelimelerini kullanmakta, ona hiçbir zaman ismiyle hitap etmemektedir. Konuşmalar sırasında da Türk toplumunun günlük yaşamına ait izleri görebilmek mümkündür. Örneğin Pepe elmalar arasındaki farklılıkları göstermek için "renklerine bak akıllım" diyerek Bebe'ye tüyo vermekte, Bebe ise aradaki farkları bulunca Pepee, "seni akıllı bıdık seni”" diyerek Bebe'ye sevgisini göstermektedir. Babası Pepee'ye "koçum”, annesi "bitanem" ya da Bebe için "merhaba fistık" gibi sıkça kullanılan hitap biçimlerini kullanmaktadır. Dede, Pepee ve Bebe'ye sıkça "kerata" diyebilmekte, şaşırdığında "Allah Allah", beğendiğinde "Maşallah", kahvaltıdan sonra "ziyade olsun", ya da çifte telli oynarken "çocuklar gelin bakayım yamacıma şöyle" diyerek Türk toplumunda sıkça kullanılan hitap biçimlerini tercih etmektedir. Yine aynı şekilde ninesi sorduğu soruyu bilince torunlarına "aferin benim akıllı bıdıklarıma" diyerek onları kutlamaktadır. Ya da kızdığında, "Aaa sizi yerden bitmeler yeter, vallahi kurbağa gibi şiştim he" diyerek tepkisini gösterir. Bu yolla dil ve söylem aracılığıyla Türk kültürüne ait söylem, hitap biçimleri ve aile içi ilişkilerin düzeni hakkında çocuklara bilgi aktarılmakta, Türk kültürüne ait söylem ve hitap biçimleri bu çizgi filmde dolaşıma sokulmaktadır.

Caillou'da ise Türk kültürüne ait yukarıda geçen söylemleri görebilmek mümkün değildir. Caillou İngilizce 'grandmother' ve 'grandfather' sözcüklerinin karşılığı olan 
'büyükanne' ve 'büyükbaba' sözcüklerini kullanmakta, dede ve nene ifadelerini hiç bir zaman tercih etmemektedir. Caillou anne ve babasına yaptıkları için sürekli teşekkür etmektedir. Esasında aile içi resmiyetin bir göstergesi olan teşekkür ederim sözünün Türk kültüründeki karşılığı 'sağol' sözcüğüdür. Buna karşın çeviride dahi 'sağol', 'maşallah' ya da 'Allah Allah' gibi Türk kültürüne ait ifadelere yer verilmemektedir. Öte yandan Caillou'da kullanılan diyaloglar ve cümle yapıları da bazen Türk kültüründekilerden farklılık göstermektedir. Örneğin babası Caillou'ya, "Caillou neden atlar için biraz saman toplamıorsun?" gibi cümleler kullanmakta, böylelikle Türk kültüründe pek de rastlanmayan bir cümle yapısı kullanmaktadır. Başka bir örnekle ifade etmek gerekirse Pepee'de nenesi Pepee'yi üzgün gördüğünde "neyin var kuzucum” diyerek durumu öğrenmeye çalışırken, Caillou'da, büyükbabası "problem nedir Caillou?” diyerek sorunu öğrenmeye çalışmaktadır. Caillou öğretmenine Bayan Martin diye hitap ederken, Pepee öğretmenine ‘öğretmenim' diye hitap etmektedir. Pepee de kullanılan dil ve hitap biçimleri daha sade, anlaşılır ve sıcakken Caillou'da kullanılan dil standartlaştırılmış, resmi bir dildir. Ayrıca çizgi filmde söylenen şarkılar ve giriş müzikleri hiçbir zaman Türkçe’ye çevrilmemektedir.

\subsubsection{Yaşam Biçimi, Kıyafet ve Aksesuarlarla Aktarılan Değerler}

Pepee'de Türkiye'nin çeşitli yörelerine ait kültürel değerlere yaşamın bir parçası olarak yer verilir. Pepee, "le hanım ha hanımey" diye 'hanımey' şarkısını söylerken şalvar giyip kuşak takmakta, ya da "Çayeli’nden Öteye" türküsünü söyleyip horon teperken Karadeniz yöresine ait giysileri, Zeybek oynarken Ege yöresine ait kıyafetleri, Trakya karşılaması oynarken Trakya yöresine ait kıyafetleri giymektedir. Bu sayede Pepee, çeşitli yörelere ait geleneksel giyim kuşam tarzları ile yaşam biçimleri hakkında birtakım bilgileri izleyicilere aktarmaktadır. Bunun yanı sıra çizgi filmde, daima oynanan halk oyunları ve kıyafetlerin hangi yörelere ait olduğu hakkında bilgi verilmektedir. Örneğin, Pepee dış ses Şuşu'nun "Hüdayda oynayalım" önerisi karşısında "Hüdayda nedir Şuşu?" diye sormakta, Şuşu ise, "Hüdayda Ankara yöremize ait türkülerimizden biridir Pepee" diyerek Pepee’yi ve izleyicileri bilgilendirmektedir. Böylelikle Türkiye'deki farklı yörelere ait kültürel değerler, yaşam biçimleri ve halk dansları izleyicilere tanıtılmakta, bu yöresel halk kültürlerinin kaybolmasının önüne geçilmektedir. Bunun yanı sıra Pepee günlük yaşamında 'erkeklere atfedilen renk' olan mavi rengi elbiselerinde tercih ederken, kız kardeşi Bebe ise pembe giysiler giymektedir. Pepee'nin ninesi başörtüsü ve gözlük takmakta, dedesi bıyık uzatarak sıradan elbiseleri giymektedir. Pepee'nin annesi etek ya da pantolon üstüne bluz, babası ise genellikle takım elbise giymektedir. Bu bakımdan Pepee'nin ailesi orta sınıf bir Türk ailesi görünümündedir. Ayrıca Pepee ve Şila örneğin doktorculuk oynarken Şila doktor kıyafeti giyip stetoskop takmakta ya da karate yaparken Pepee karate elbisesi giyebilmektedir. Bebe ise çoğunlukla ağzında emzikle dolaşmaktadır.

Caillou'nun izleyici kitlesi farklı milletlerden ve kültürlerden oluştuğu için çizgi filmdeki karakterlerin giysileri standart Batılı bir görünümdedir. Buna karşın çizgi filmde zaman zaman farklı kültürlere ait, fakat gittikçe popülerleşen, çeşitli giysileri de görebilmek mümkündür. Örneğin Çin yılını kutlarken, çizgi filmde geleneksel uzak doğu kıyafetlerini giyen birilerini görmek mümkündür. Caillou'nun babası işe giderken takım elbise ve el çantası kullanırken, günlük yaşamında kazak pantolon gibi elbiseleri tercih etmektedir. Büyükbabası ve büyükannesi ise standart Batılı görünümde günlük elbiseler giymektedir. Caillou'nun annesi ve bayan öğretmeni genellikle bol kesim pantolon ve gömlekler giymektedir. Pepee'deki gibi yöresel kıyafetler ya da Türk kültürüne ait geleneksel ya da yöresel kıyafetleri Caillou'da görebilmek mümkün değildir. Öte yandan Pepee'nin kız 
kardeşi Bebe'nin ağzından emzik eksik olmazken, Caillou'nun kız kardeşi Rozi emzik kullanmamaktadır.

\subsubsection{Yemekler ve Mutfak Kültürüne İlişkin Değerler}

Pepee'de Türk mutfağına ilişkin yiyecek ve içecekleri sıklıkla görmek mümkündür. Örneğin Pepee, geniş ailesiyle beraber pikniğe gidip orada kahvaltı yaparken, annesi Pepee'ye "ne yemek istersin Pepee" diye sorar, Pepee ise "pekmezli, tahinli ekmek yemek istiyorum anne" der. Piknikte, kahvaltı masasının üstündeki yumurtalıkta herkes için birer tane suda pişmiş yumurta, kahvaltı masasının üzerinde ise küçük bir piknik tüpü ile üstünde kaynamakta olan bir çaydanlık ve demlik bulunmaktadır. Pepee, başka bir bölümde karnı acıkınca Şuşu'dan köfte ister, yine aynı bölümde üç tane köfte ile doymayan Pepee'ye Şuşu yanında domatesli karnabahar veya pırasa gibi geleneksel Türk mutfağına ait sebze yemekleri sunar. Farklı bir bölümde ninesi Pepee ve Şila için bahçede sac üzerinde patatesli ve kıymalı gözleme yapar. Bilindiği üzere Türk mutfağında yoğurt ve beyaz ekmek önemli bir yere sahiptir. Pepee, yemeklerinde 'ekmek ve bir kase yoğurt' yemeyi çok sevdiğini söyler. Pepee'nin en sevdiği tatlı ise ise geleneksel Türk tatlılarından biri olan sütlaçtır.

Caillou'da ise Batılı bir mutfak kültürünün temsili bulunmaktadır. Caillou'nun en sevdiği yiyecekler arasında pizza, sandviç ve yaban mersinli çörek bulunmaktadır. Caillou'nun ailesinde de hazır yiyeceklere önem verilmektedir. Caillou ve ailesi kahvaltıda mısır gevreği ve tahıllı gevrekleri tüketmeyi tercih etmektedir. Caillou bir bölümde anne ve babası için sürpriz kahvaltı hazırlarken, annem "tahıllı cornflakes sever, babam ise mısır gevreğini çok sever" diyerek onların da sabahları bu tarz hazır yiyecekleri tükettikleri hakkında bilgi vermektedir. Caillou ve ailesi ayrıca kahvaltıda tereyağı ve kek gibi yiyecekler yemektedir. Caillou ve ailesi her cuma günü akşam yemeğinde pizza sipariş ederler. Hatta Caillou ile ailesi hem oyun hem de değişiklik olsun diye bazı bölümlerde, evde peynirli, mantarlı ve biberli gibi çeşitli şekillerde pizza yaparlar. Caillou'da küresel anlamda farklı ülkelerin de yemek kültürlerine ait izleri görebilmek mümkündür. Örneğin Çinli arkadaşı Sera'nın ona Çin kültürü ve Çin yeni yılı hakkında bilgi verdiği bir bölümde Sera, Caillou'yu Çin bölgesine götürüp ona tahta çubuklarla Çin yemeği yedirir.

Çizgi filmde Caillou'nun kedisi Gilbert'a dahi hazır kedi maması verilirken Pepee'nin köpeği Köpüş’e, nenesi tarafından artan kuru fasulyeden verilmektedir. Görüldüğü üzere Caillou'da yemek kültürü hazır yiyeceklere ve farklı ülkelerin yemek kültürlerine dair imgeler yer alırken, Pepee'de Türk mutfağı ve yemek kültürü hakkında bilgiler çocuklara aktarılmaktadir.

\subsubsection{Danslar, Halk Oyunları ve Şarkılara İlişkin Kültürel Değerler}

Pepee isimli çizgi film için seçilen videolar arasında modern danslara ilişkin herhangi bir veriye ulaşılamamıştır. Buna karşın Pepee'yi sıklıkla "horon teperken", "Ankara hüdaydası", "Trakya karşılaması", "Çayda çıra" ve "Atabarı" oynarken, "halay çekerken" hatta bunların tamamını aynı bölümde yaparken görebilmek mümkündür. Çizgi filmde Türkiye'nin değişik yörelerine ait halk oyunları oynanırken, bu yörelerdeki kültüre, kıyafete ve yaşam biçimine dair bilgiler de aktarılmaktadır. Örneğin Pepee horon teperken dış ses Şuşu'ya, "horon teperken söylediğimiz Karadeniz uşağındaki uşak ne demek" diye sormakta, Şuşu ise, "Karadeniz bölgesinde 'uşak' kelimesinin anlamının çocuk” olduğunu ve "Karadeniz uşağının kelimesinin Karadeniz çocuğu” anlamına geldiğini söyleyerek Karadeniz yöresi hakkında çocuklara bilgi aktarmaktadır. Buna ek olarak Pepee'nin dedesinin en sevdiği halk oyunu "Trakya karşılaması", babasının en sevdiği halk oyunu "horon", eniştesi ve teyzesinin en sevdikleri halk oyunu ise "çayda çıra"dır. Pepee 
Atatürk'ün de en sevdiği oyun olan "Atabarı"yı oynamayı çok sevmektedir. "Hanımey" türküsü pepenin en sevdiği türküdür, Pepee bunun yanı sıra "Hüdayda", "Çayeli'nden Öteye" ve "Susadım Su İsterim" türkülerini söylemeyi ve bu türküler eşliğinde halk oyunlarını oynamayı çok sevmektedir. Görüldüğü üzere Pepee aracılığıyla çocuklara Türkiye'ye ait türküler, yöresel halk oyunları ve yaşam biçimleri hakkında bilgiler aktarılmaktadır.

Caillou isimli ise çizgi filmin incelenen bölümlerinde ise Türk kültürüne, halk oyunlarına, türkülerine ya da yaşam tarzlarına ilişkin herhangi bir bilgiye rastlanılamamıştır. Pepee dedesiyle horon teperken, Caillou ise büyükannesiyle Batılı türde dans etmektedir. Yine büyükanne ve büyükbaba çalan Batılı bir müzik eşliğinde Caillou'nun önünde dans etmektedir. Caillou'nun çizgi filmin başlangıcında söylediği şarkı da dahil olmak üzere söylediği ve dinlediği şarkıların tamamı İngilizce'den Türkçe'ye çevrilmeden orijinal verilmektedir. Bu durum Hall'ın "küresel kitle kültürü, Batı merkezlidir ve daima İngilizce konuşur" (1998: 49'dan akt. Akça, 2008) söylemini destekler niteliktedir.

\subsection{6. Çocuk Oyunları}

Pepee'de oynanan çocuk oyunları geleneksel Türk çocuklarının oynadıkları oyunlardır. $\mathrm{Bu}$ oyunlar arasında, saklambaç, evcilik, kartopu ve misket gibi oyunlar bulunmaktadır. Pepee dedesinin yaptığı tahta misketleri boyayarak onlarla oynamakta, dedesiyle beraber uçurtma yaparak uçurmakta, hatta kuzeni Şila ile beraberde uçurtma uçurmayı çok sevmektedir. Pepee bunun yanı sıra futbol da oynamaktadır. Pepee, kardeşi Bebe ve Şila çok nadir olarak oyuncaklarla tek başlarına oynamaktadır. Bunun yerine birlikte ve paylaşarak oyun oynamayı tercih etmektedirler.

Caillou ise tek başına oyuncaklarıyla oynamayı çok sevmektedir. Hatta kardeşi Rozi’yi dahi zaman zaman kendi oyunlarına dâhil etmek istememektedir. Bu bakımdan bireycilik Caillou'da daha ön plandadır. Bunun yanı sıra Caillou'nun çok sayıda oyuncağı bulunmakta, hatta Caillou ve kız kardeşi Rozi geceleri uyurken kucaklarında oyuncakları ile beraber uyumaktadırlar. Caillou'nun en sevdiği oyuncağı anne ve babasının doğum gününde hediye ettikleri dinozordur. $\mathrm{Bu}$ doğrultuda Batılı tüketim kültürü Caillou'daki oyun anlayışına yansımaktadır. Ayrıca Caillou, büyükbabasıyla futbolun yanı sıra Türkiye'de pek de bilinmeyen oyunlardan beysbol ve kroket gibi oyunlar oynamakta, anne ve babasıyla buz hokeyi maçı izlemekte ve buz pateni yapmaktadır. Öte yandan Pepee'nin oyun arkadaşları genellikle akrabalarından oluşurken, Caillou'nun oyun arkadaşları farklı etnik kökenlere sahiptir. Örneğin Clementine ve ikizler Jason \& Jeffrey siyahi, Sarah ise uzak doğuludur. Buna karşın en yakın arkadaşı Leo ise Batılıdır. Görüldüğü üzere Caillou'daki Batılı yaşam biçimi, çocuk oyunları aracılığıyla da izleyiciye yansımaktadır.

\subsection{7. İnanç ve Milli Hassasiyetlerle İlgili Aktarılan Değerler}

Pepee ve Caillou'nun bu çalışma kapsamında izlenilen bölümlerinde dini inanışlarla ilgili herhangi bir veriye ulaşılamamıştır. Buna karşın Pepee'de milli hassasiyetlere ve değerlere oldukça sık bir şekilde yer verilmektedir. Pepee başlangıç müziğinde elinde bir Türk bayrağı ile izleyenleri selamlamakta, "milli değerlere sahip Türk çocuk kahramanı" profili çizmektedir. Pepee 23 Nisan gibi milli bayramlarda bu bayramların konseptine uygun bir şekilde hareket etmekte, bayramın önemi hakkında çocukları bilgilendirmektedir. Örneğin 23 Nisan'da Pepee ve Bebe her yeri bayraklarla ve kırmızı beyaz balonlarla süsler. Dedeleri eve gelince, "aferin çocuklar demek unutmadınız bayramı" der. Pepee, "unutmadık dede unutmayacağız" derken kız kardeşi Bebe, "23 Nisan bütün dünyadaki 
çocukların bayramı, hiç unutulur mu dede?" diyerek 23 Nisan'ın önemine değinir. Daha sonra 23 Nisan'ın neden Atatürk tarafından çocuklara armağan edildiğini Bebe şöyle anlatır:

"Bundan çok uzun zaman önce bizim ülkemize, kötü insanlar, yani düşmanlar gelmiş, ülkemizi ve özgürlügümüzü almak istemişler... Ama Atatürk'ümüz ve onun yanında olan herkes buna izin vermemiş, önce düşmanları yurdumuzdan kovmuş ve sonra da 23 Nisan'da özgürlüğümüzü herkese duyurmuş ve bu mutlu günü özgürlüğü en iyi koruyacak olan biz çocuklara bayram olarak armağan etmiş. Hem de sadece bizim ülkemizdeki çocuklara değil tüm dünyadaki çocuklara armağan etmiş.” (Show TV 23 Nisan Özel Yayın1).

23 Nisan'da yaşanan geleneksel kutlamalar bu çizgi filmde gösterilerek bu kutlamaların ve bayramın öneminin yaşatılması sağlanır. Caillou'da ise, incelenen videolar içerisinde dini veya milli herhangi bir sembol ya da değere yer verilmediği görülmektedir.

\section{Sonuç}

Çalışmanın başında da belirtildiği gibi bu makale çizgi filmlerin kültürel bir mücadele alanı olduğu tezini ileri sürmekte, bunu Türkiye'de en çok izlenen ulus aşırı çizgi filmlerden Caillou, yerel çizgi filmlerden de Pepee isimli çizgi filmlerin analizi yoluyla ortaya koymaktadır. Bu çizgi filmlerden Caillou, Batıya ait değer ve yaşam biçimlerini yeni nesillere aktarırken, Pepee, yerel kültüre ait değerleri ve yaşam biçimlerini izleyicilerine aktarmaktadır. Bu doğrultuda çizgi filmlerin yerel ve küresel kültüre ait değerlerin aktarılması bakımından bir 'mücadele alanı' konumunda olduğunu söylemek mümkündür. Çoğunlukla Batı'ya ait değer yargılarını içeren küresel kültürün ulus aşırı çizgi filmlerle aktarılması, bu kültürün yaygınlaşmasına ve yeni nesiller tarafından içselleştirilmesine sebebiyet vermektedir. Bu çizgi filmlerde göstermeme ya da hatırlatmama yollarıyla yeni nesillerin kendi kültürlerine yabancılaşmaları sağlanmaktadır. Ulus aşırı üne sahip çizgi filmlerle yerel kültürler unutturulmakta, yerine herkesin ortak paydasına hitap eden, standartlaştırılmış ve Batıya ait değerleri taşıyan küresel bir kültür oluşturulmakta, yeni nesillerin de bu 'yeni kültürü' içselleştirmeleri hedeflenmektedir.

Henry A. Giroux'un da ifade ettiği gibi çizgi filmler, "toplumsal değerleri öğretme hususunda aile, okul ya da dini kurumlardan daha güçlü” olabilmektedir (Muratoğlu 2009: 78). Bu durumun oluşmasında televizyonun da önemli bir etkisi bulunmaktadır. Televizyon teknolojik özelliklerinin de etkisiyle izleyicilerinin dikkatini çekmekte, olayların düşünsel boyutlarını ikinci plana atarak, bireyleri olayların neredeyse bir tür görgü tanığı konumuna getirmektedir. Bireylerin yaşamları üzerinde önemli ölçüde etkili olan televizyonun bilinçli kullanımı, bu bakımdan önem kazanmaktadır. Bu çalışmanın inceleme kısmında da görüldüğü üzere televizyon programları aracılığıyla yeni nesillere kültür ve yaşam biçimleri hakkında düzenli olarak bilgi ve içerikler aktarılmaktadır. Aktarılan bu bilgi ve içerikler, bireylerin yaşam biçimleri üzerinde etkili olmaktadır. Bu bakımından çizgi filmlerin eğitici ve öğretici boyutlarının dikkatlice incelenmesi gerekmektedir.

Çizgi filmler aracılığıyla yeni nesillerin zihinlerine hangi fikirlerin ya da değer yargılarının ekildiğinin sistematik olarak incelenmesi, bu doğrultuda yeni nesillerin korunmasına yönelik çalışmaların yapılması ve özellikle medya okur yazarlığı hakkında ailelerin bilinçlendirilmesine yönelik sosyal programların geliştirilmesi gerekmektedir. Çizgi filmlerin etkileme gücünden yerel kültürlerin de istifade edebilmesi için yerel kültüre ait değerleri içeren çizgi filmlerin desteklenmesi ve yaygınlaşması elzemdir. Bu durum, küresel kültür karşısında yerel kültürlerin korunmasına ve yeni nesillere aktarılmasına 
imkân verecektir. Bu bakımdan Pepee, Niloya, Keloğlan, Nasrettin Hoca ve benzeri çizgi filmler, Türk kültürüne ve yaşam biçimine ait değerlerin yeni nesillere aktarması ve yerel kültürleri yeni nesillerin içselleştirmesi bakımından önem taşımaktadır.

\section{KAYNAKÇA}

Akça, E. (2012). "Küreselleşme Üzerine Bir Tartışma: Kültürel Emperyalizm ve Kültürel Küreselleşme Tezleri” Siyasal Iletişim Enstitüsü, http://www.siyasaliletisim.org/dr-bahadr-kaleaas/yrd-doc-dr-emel-akca/224-kueresellemeuezerine-bir-tartma-qkueltuerel-emperyalizmq-ve-qkueltuerel-kueresellemeq-tezleri.html (Son Erişim Tarihi: 2016, Mayıs 29)

Akçalı, S. İ. (2009). Tüketim toplumunda çocukluğun yitişi. S. Akçalı (Ed.). Çocuk ve medya (İkinci bask1) İçinde (s. 1-13). Ankara: Nobel.

Albrow, M. ve King, E. (Eds.) (1990). Globalization, Knowledge and Society. London: Sage.

Araslı, A., Pilgir, A. (2010, Aralık 20). Miniklerin kalbini "Kayyu" ile kazandı. Yeni Asir. Retrieved from: http://www.yeniasir.com.tr/ekonomi/2010/11/21/miniklerin kalbini_kayyu_ile_kazandi (Son Erişim: 21 Mayıs 2016)

Atan, U. (1995). Animasyonun Kültür Aktarımındaki Yeri. Yayınlanmamış Yüksek Lisans Tezi. Selçuk Üniversitesi, Sosyal Bilimler Enstitüsü: Konya.

Banerjee, I. (2002). The locals strike back? Media globalization and localization in the new asian television landscape. Gazette: The International Journal for Communication Studies, 64(6), 517-535.

Benk, S. ve Akdemir, T. (2004). "Globalleşme ve Ekonomik Değişim”, Çimento Işsveren, Vol. 18 (1).

Çilingir, A. (2014). Popüler Kültür İçerisinde Çocuk Edebiyatı Ürünlerinin Yeri. I. Uluslararası Çocuk ve Gençlik Edebiyatı Sempozyumu. 24-25 Ekim 2014 Maltepe İstanbul. 143-149.

Doğan, H. (2005). Küreselleşme Sürecinde Kültürel Değişim ve Medya İlişkisi: Ankara'da Corn Flakes Tüketimi Örneği. Yayımlanmamış Yüksek Lisans Tezi. Ankara Üniversitesi Sosyal Bilimler Enstitüsü: Ankara.

Dursun, Ç. (2001). Televizyon Haberlerinde İdeoloji, Ankara: İmge Kitabevi.

Erbaş, P. (2012, Haziran 3). Pepee bu vatanın evladıdır. Haber Türk Gazetesi. Retrieved from: http://www.haberturk.com/medya/haber/747675-pepee-bu-vataninevladidir (Son Erişim: 29 Mayıs 2016)

Erdoğan, İ. (1998). Gerbner'in Ekme Tezi ve Anlattığ Değerlendirme. Kültür ve Illetişim Dergisi, Vol. 1(2) 149-180.

Erdoğan, İ. (2014). Medya Teori ve Araştırmaları: Biliş ve Davranış Yönetimi Amaçlı Endüstri, Devlet ve Üniversite İşbirliğinde, Medyanın Egemen ve Alternatif Açılamaları. Ankara: ERK Yayınları.

Erdoğan, İ. Alemdar, K. (2010). Öteki Kuram: Kitle iletişim Kuram ve Araştırmalarının Tarihsel ve Eleş̧tirel bir Değerlendirmesi (3. Bsk.). Ankara: Erk.

Giddens, A. (2010). Modernliğin Sonuçları, E. Kuşdil (Çev.), İstanbul: Ayrıntı Yayınları. 
Giddens, A. (2013). Sosyoloji, C. Güzel (Çev.),, İstanbul: Kırmızı Yayınları.

Giroux, H. (1999). The Mouse that Roared: Disney and the End of Innocence. New York: Rowman \& Littlefield Publisher, Inc.

Göçer, A. (2012). Dil-Kültür İlişkisi ve Etkileşimi Üzerine. Türk Dili, Vol. 729. 50-57.

Gunter, B. (1987). Poor Reception: Misunderstanding and Forgetting Brodcast News. Hillsdale, Lawrence Erbaum Associates: New Jersey and London.

Güler, D. (2013). Soyutun Somutlaştırılması: Çizgi Filmlerin Kültürel İşlevleri. 1. Türkiye Çocuk ve Medya Kongresi. Bildiri Kitabı (ss. 207 - 216). 14-15 Kasım 2013, İstanbul.

Hall, S. (1998). "The Local and the Global: Globalization and Ethnicity", Anthony D. King (ed.) Culture, Globalization and the World System, New York: Macmillan

Herman, E., McChesney, R. (1997). The Global Media, London: Cassell.

Katz, E., Gurevitch, M., \& Haas, H. (1973). On the Use of the Mass Media for Important Things. American Sociological Review, 38 (2), 164-181.

Keloğlu İşler, E. İ. (2014, Ocak 14). Kültürel Ekme Kuramı Bağlamında Türkiye Üretimi Çizgi Filmler ve Çocuk Bilincinin İnşası. Retrieved from: www.iletisimvediplomasi.com/kulturel-ekme-kurami-baglaminda-turkiye-uretimi-cizgifilmler-ve-cocuk-bilincinin-insasi-yrd-doc-dr-esra-i-keloglu-isler/ (Son Erişim Tarihi: 25 Kasim 2016)

Ker-Dincer, M. ve Yılmazkol, Ö. (2009). "Televizyon: Çocuklara "Gerçek Hayat"1 Şiddetle Öğreten Çağdaş Masal Anlatıcısı", İçinde Akçalı, S. İ. (2009). Çocuk ve Medya, (ss.189-210). Ankara: Nobel Yayıncılık.

Kongar, E. (1986). Kültür ve İletişim, İstanbul: Say Yayınları.

Mahiroğulları, A. (2005). Küreselleşmenin Kültürel Değerler Üzerine Etkisi. Sosyal Siyaset Konferanslarl Dergisi, Vol. 50 (1). 1275 - 1288.

Marsh, J. and Millard, E. (2000). Literacy and Popular Culture: Using Children's Culture in the Classroom, London: Paul Chapman.

Mattelart, A. ve Mattelart, M. (1992). Rethinking Media Theory: Signposts and new directions. University of Minnesota Press: Minessota.

McLuhan, M. (1962). The Gutenberg Galaxy: The making of Typographic Man. Toronto: University of Toronto Press.

Mora, N. (2008). Medya ve kültürel kimlik. Uluslararası Insan Bilimleri Dergisi. Vol. 5 (1). 1-14.

Muratoğlu, B. (2009). "Sosyal Sapkınlığın Medyadaki Temsilinin Çizgi Filmler Üzerinden İncelenmesi”, Yayımlanmamış Yuksek Lisans Tezi, İstanbul: İstanbul Üniversitesi SBE.

Oğuz, M. Ö. (2009). Somut Olmayan Kültürel Miras Nedir?. Ankara: Geleneksel Yayıncılık.

Öğüt, E. (2010). Somut Olmayan Kültürel Mirasın Aktarımına Bir Bakış: Geleneksel Çocuk Oyunlarının Yaşatılması İçin Öneriler. Kültür ve Turizm Bakanlığı Araştırma ve Eğitim Genel Müdürlüğü. Yayımlanmamış Uzmanlık Tezi: Ankara 
Postman, N. (1994). Televizyon Öldüren Eğlence, O. Akınhay (Çev.),, İstanbul: Ayrintı.

Powers, S. ve Postman, N. (1996). Televizyon Haberlerini İzlemek. Çev. Aslı Tunç, İstanbul: Kavram Yayınları.

Robertson, R. (1992). Globalization: Social Theory and Global Culture (Reprint. ed.). London: Sage.

Robertson, R. (1999). Küreselleşme: Toplum Kuramı ve Küresel Kültür, Çeviren: Hüsrev Yolsal, Ankara: Bilim ve Sanat Yayınları.

Schiller, H. (1991). "Not Yet the Post-Imperialist Era." Critical Studies in Mass Communication 8(1). Ss.13-28.

Şeker, M. ve Gölcü, A. (2008). Futbolun Televizyonda Yeniden Üretimi, İletişim Kuram ve Araştırmaları Dergisi, Vol. 26, Kış-Bahar Sayısı, 115-134.

Terkan, N. (2011). Çocuk ve Medya Popüler Çocuk Dergilerinde Egemen Söylemlerin Kuruluşu, Ankara: Savaş Yayınları.

Tomlinson, J. (1999). Kültürel Emperyalizm: Eleştirel Bir Giriş. E. Zeybekoğlu (Çev.). İstanbul: Ayrıntı Yayınları

Tomlinson, J. (2013). Küreselleşme ve Kültür. A. Eker (Çev.). İstanbul: Ayrıntı Yayınları

TUİK. (2013, Ağustos 22). 06 - 15 Yaş Grubu Çocuklarda Bilişim Teknolojileri Kullanımı ve Medya, 2013. Alinan Yer: http://www.tuik.gov.tr/PreHaberBultenleri.do?id=15866 (Son Erişim Tarihi: Nisan 23, 2016)

Türkmen, N. (2012). Çizgi Filmlerin Kültür Aktarımındaki Rolü ve Pepee, Cumhuriyet Üniversitesi Sosyal Bilimler Dergisi, Vol 36 (2). 139-158.

Yavuz, S. (2011, Mayıs 18). Çocuklarda Caillou(Kayu) çılgınlığı ve olumsuz etkileri. Retrieved From: http://www.milliyet.com.tr/cocuklarda-caillou-kayu--cilginligi-veolumsuz-etkileri-pembenar-yazardetay-aile-1391749/ (Son Erişim: 21 Mayıs 2016)

Yaylagül, L. (2010). Kitle İletişim Kuramları: Egemen ve Eleştirel Yaklaşımlar. 3. Baskı, Ankara: Dipnot Yayınları.

Yorulmaz, B. (2013a). Din ve Değerler Eğitimi Açısından Caillou Çizgi Filminin Değerlendirilmesi. Diyanet İlmi Dergi, Vol. 49 (3), 127-143.

Yorulmaz, B. (2013b). Pepee Çizgi Filminin Din ve Değerler Eğitimi Açısından Değerlendirilmesi. Uluslararası Sosyal Araştırmalar Dergisi, Vol. 24 (6), 438-448. 